\title{
THE STUDENT'S ENHANCEMENT OF MULTIPLE REPRESENTATION ABILITY USING MERRILL'S FIRST PRINCIPLES OF INSTRUCTION
}

\author{
Hestu Wilujeng ${ }^{1}$, Retno Andriyani ${ }^{2}$ \\ ${ }^{1}$ Institut Agama Islam Negeri Ponorogo, Jl Pramuka No 156, Ponorogo, Indonesia \\ ${ }^{2}$ Universitas Muhammadiyah Tangerang, JL Perintis Kemerdekaan NO 133 Tangerang Indonesia \\ e-mail: hestu@iainponorogo.ac.id
}

\begin{abstract}
A learning process in schools realizes the purpose of this education. Mathematical multi representation ability is one of the general goals of teaching mathematics in schools. This research is quasi-experimental. The amount of increase before and after learning is calculated by the normalized gain formula. There is a difference in the increase in mathematical multi-representation abilities of students who receive Merril's First Principles of Instruction (MFPI) than conventional learning based on high and medium mathematical preliminary knowledge (MPK). By contrast, at low MPK, there is no difference in increasing multi representation abilities. Most students use mathematical representations. The percentage of students using more than two representations is $40 \%$. MFPI learning affects students with high MPK and medium MPK but does not affect students with low MPK category. At the MFPI learning stage, low MPK students lack initial knowledge that can be used to form new knowledge.
\end{abstract}

Keywords: Multiple Representation Ability, Merrill's First Principles of Instruction

\begin{abstract}
Abstrak
Sebuah proses pembelajaran di sekolah mewujudkan tujuan dari pendidikan ini. Kemampuan multi representasi matematis merupakan salah satu tujuan umum pengajaran matematika di sekolah. Penelitian ini merupakan penelitian eksperimen semu. Besarnya kenaikan sebelum dan sesudah pembelajaran dihitung dengan rumus gain ternormalisasi. Terdapat perbedaan peningkatan kemampuan multirepresentasi matematis siswa yang mendapat pembelajaran MFPI dibandingkan dengan pembelajaran konvensional berbasis KAM tinggi dan kemampuan awal matematika sedang. Sebaliknya pada kemampuan matematis awal yang rendah tidak terdapat perbedaan peningkatan kemampuan multirepresentasi. Sebagian besar siswa menggunakan representasi matematis. Persentase siswa yang menggunakan lebih dari dua representasi adalah 40\%. Pembelajaran MFPI berpengaruh pada siswa dengan KAM tinggi dan sedang tetapi tidak berpengaruh pada siswa dengan kemampuan awal matematika rendah. Karena pada tahap pembelajaran MFPI, kemampuan awal matematika siswa yang rendah kurang memiliki pengetahuan awal yang dapat digunakan untuk membentuk pengetahuan baru.
\end{abstract}

Kata kunci: Kemampuan Multirepresentasi, Merrill's First Principles of Instruction

\section{INTRODUCTION}

National education functions to educate the nation's life through developing the potential of every citizen without exception. Quality national education is the foundation for developing superior human resources and can proactively respond to the challenges of a changing era (PP, 2021). Education in Indonesia, one of which is secondary education. Secondary education aims to improve intelligence, knowledge, personality, good morals, 
and skills to live independently and pursue further education. A learning process in school realizes the purpose of this education. Schools become a place for the acquisition of knowledge and skills and the formation of attitudes in developing students' potential.

One of the potentials obtained by students in the learning process at school is mathematics. In this era of globalization, every sector of life is an application of mathematical material. Therefore mathematics is studied during the learning process at school. Mathematics is a valuable universal science for human life, underlies modern technology development, has an essential role in various disciplines, and advances the power of human thought. To master technology in the future, it is necessary to have a vital mastery and understanding of mathematics from an early age. Wilujeng (2019) state mathematics is not just counting but as a tool to develop abilities such as problem solving, communication and thinking tools that can help humans in solving problems in life. One of them is mastery of mathematical multi-representation.

Mathematical multirepresentation ability is one of the general goals of teaching mathematics in schools. The same concept can be explained through multiple representations by different types of representational modes (Ainsworth, 1999). Multirepresentation can also be interpreted to represent the same concept in different forms, namely verbal, mathematical, picture, and graphic. Kusumah (2016) asserts representation as a way for students to reinterpret a problem in a simple form based on their understanding and communicate the solutions obtained through representations in the form of verbal, symbolic, or visual. With multiple mathematical representations, problems that initially look complicated can be seen more quickly and simply so that the problems presented can be solved more easily.

In mathematics learning, when students are given a problem, the steps in solving the problem tend to be the same as the examples given by the teacher. Based on the researchers' observations, most students imitate and memorize the way the teacher solves the problem because they assume that the answer given by the teacher in the example is the only correct answer. In addition, mathematics teachers prefer simple test forms such as multiple choice and filling in blank questions rather than providing complex problem solving. Lesh (1987) state those studies were problem-solving to acquire knowledge through the first and second steps in problem solving proposed. They rarely have the opportunity to explain 
their solution using oral or written problem solving. In addition, problem-solving provides questions that allow students to answer in more than one way, so students' ability to express ideas or ideas is low.

The success of increasing mathematical multi-representation abilities depends not only on the students themselves, but the presence of teachers and learning in schools also plays a role in improving these abilities. Teaching that facilitates the improvement of mathematical multi-representation skills is Merrill's First Principles of Instruction (MFPI) (Smaldino et al., 2008). Wilujeng (2019) states MFPI is teaching that has basic principles, namely teaching facilitates students to be involved in solving real problems, teaching that facilitates students to activate existing knowledge as a basis for new knowledge, teaching that facilitates students to gain new knowledge, teaching that facilitates students to apply knowledge into the context of problems given by the teacher, teaching that facilitates students to integrate new knowledge into the world of students. MFPI teaching is problemcentered and involves students in four phases: activation, demonstration, application, and integration.

The relationship between MFPI and mathematical multi-representation abilities is that MFPI always begins with a problem because by familiarizing students with problems, students are required to solve these problems. At the demonstration stage, the teacher encourages students to represent and model the problem into a more straightforward form so that it is easier to solve. Wilujeng (2019) states that students who are accustomed to discussing in solving mathematical problems, this habit will make students become reliable, critical, and creative problem solvers.

\section{METHODS}

Based on the research objectives, this research is quasi-experimental. In this quasiexperimental, the subjects were not grouped randomly, but the researcher accepted the condition of the subjects as they were. This study used two groups, namely the experimental group and the control group. The experimental group was given the Merrils First Principles of Instruction (MFPI) learning, and the control group was given the usual conventional learning. The grouping of students who received MFPI learning and 
conventional learning and the categories of high MPK, Medium MPK, and low MPK as follows,

Table 1. Number of Students Based Mathematical Preliminary Knowledge Receive MFPI Learning and Conventional Learning

\begin{tabular}{cccccccc}
\hline \multicolumn{4}{c}{ MFPI } & \multicolumn{5}{c}{ Conventional } \\
\hline High & Medium & Low & Total & High & Medium & Low & Total \\
\hline 5 & 23 & 3 & 31 & 7 & 19 & 3 & 29 \\
\hline 10 & 18 & 5 & 33 & 3 & 22 & 6 & 31 \\
\hline 15 & 41 & 8 & 64 & 10 & 41 & 9 & 60 \\
\hline
\end{tabular}

Table 1 describes the number of students who received MFPI learning with the criteria of high MPK as many as 15 students, medium MPK as many as 41 students, and low MPK as many as 8 students. In the class that received conventional learning with the criteria of high MPK as many as 10 students, medium MPK as many as 41 students, and low MPK as many as 9 students. The instrument used in the research is a test of mathematical multirepresentation abilities. The amount of increase before and after learning is calculated by the normalized gain formula developed by Hake (1999) as follows:

$$
\text { Gain Index }(g)=\frac{\text { postestscore }- \text { pretestscore }}{\text { idealscore }- \text { pretestscore }}
$$

\section{RESULTS AND DISCUSSION}

The results of the inferential statistical data analysis depend on the normality of the data and the homogeneity of the variance. The data normality test aims to determine the statistics used to test the average difference between the two classes.

Table 2. Normality Test of Students' Mathematical Multi-Representation Ability Improvement Based on Mathematical Premilinary Knowledge Category

\begin{tabular}{|c|c|c|c|c|c|c|c|}
\hline Categor & & Learning & $\mathrm{N}$ & SW & Sig. & $\mathrm{H}_{\mathrm{o}}$ & Interpretation \\
\hline \multirow{6}{*}{$\begin{array}{l}\text { Mathematical } \\
\text { Premilinary } \\
\text { knowledge }\end{array}$} & \multirow{2}{*}{ High } & MFPI & 15 & 0,853 & 0,019 & Rejected & Not Normal \\
\hline & & Conventional & 10 & 0,869 & 0,097 & Accepted & Normal \\
\hline & \multirow{2}{*}{ Medium } & MFPI & 41 & 0,977 & 0,567 & Accepted & Normal \\
\hline & & Conventional & 41 & 0,893 & 0,001 & Rejected & Not Normal \\
\hline & \multirow{2}{*}{ Low } & MFPI & 8 & 0,918 & 0,415 & Accepted & Normal \\
\hline & & Conventional & 9 & 0,976 & 0,939 & Accepted & Normal \\
\hline
\end{tabular}


In Table 2 it can be seen that for low MPK, the value of Sig. the data on increasing mathematical multi-representation ability is more than 0.05 , so the null hypothesis is accepted. In conclusion, the data on increasing mathematical multi-representation ability for low MPK is typically distributed. Medium MPK and high MPK, the Sig value of the data on increasing mathematical multi-representation abilities is less than 0.05 as a result, the null hypothesis is rejected so that it concluded that the data for the increase in medium MPK and high MPK are not normally distributed, the next step is to perform the MannWhitney test.

Table 3. Test of Homogeneity of Data for Increasing Students' Mathematical MultiRepresentation Ability based on Low Mathematical Preliminary Knowledge

\begin{tabular}{ccccccc}
\hline Category & Learning & $N$ & $F$ & $\begin{array}{c}\text { Sig } \\
\text { Hom }\end{array}$ & $\boldsymbol{H}_{\mathbf{0}}$ & Interpretation \\
\hline \multirow{2}{*}{ Low MPK } & MFPI & 8 & 1,327 & 0,267 & $\begin{array}{c}\text { Accept } \\
\text { ed }\end{array}$ & Homogenous \\
\cline { 2 - 5 } & Conventional & 9 & & &
\end{tabular}

Table 3 shows that Sig. data on increasing students' mathematical multirepresentation abilities based on the low MPK is more than 0.05 so that the null hypothesis is accepted. In conclusion, the data on increasing students' mathematical multirepresentation abilities based on low MPK has a homogeneous variance.

Table 4. Test of Differences in Students' Mathematical Multi-Representation Ability Improvement Based on Mathematical Preliminary Knowledge

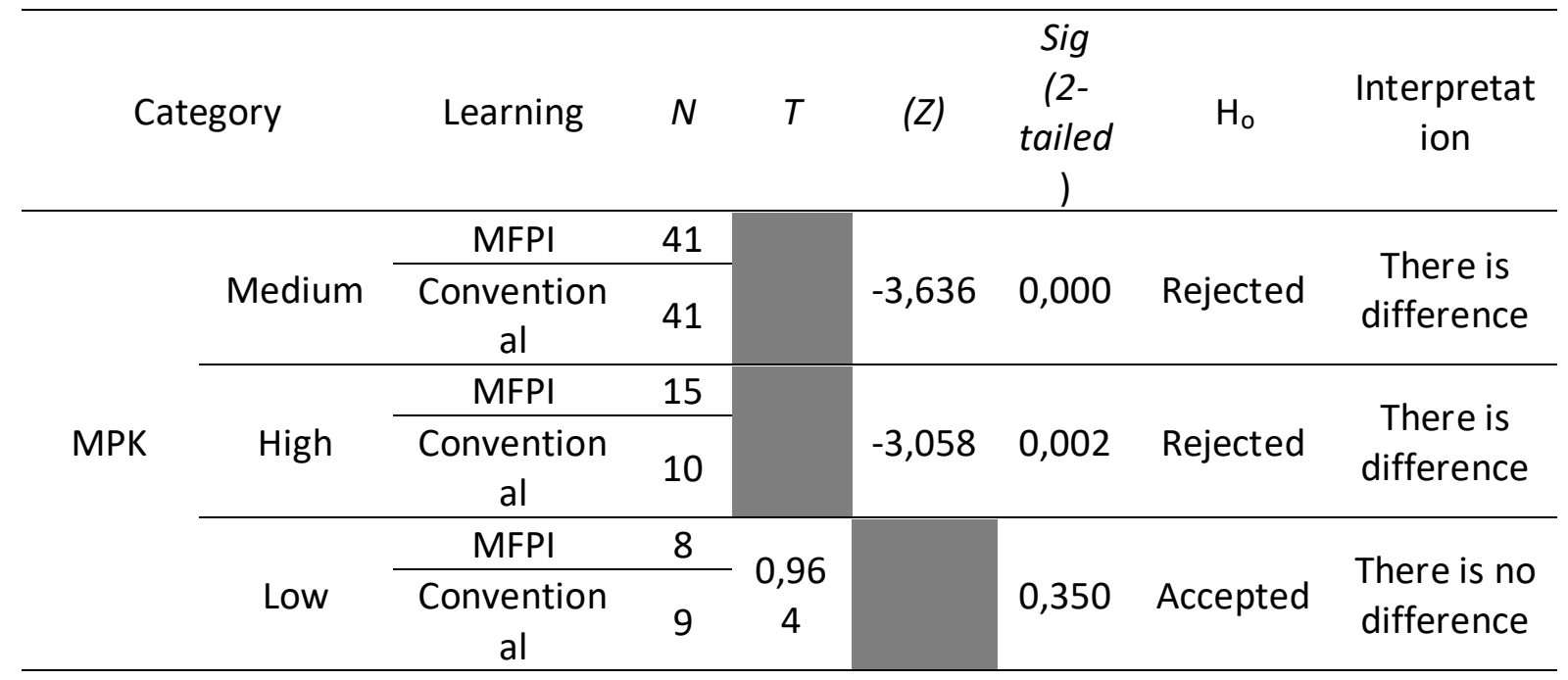


Table 4 shows that the Sig data on increasing students' mathematical multirepresentation abilities based on medium MPK and high MPK is less than 0.05 , so the null hypothesis is rejected. The conclusion is that there are differences in the increase in the mathematical multi-representation ability of students who receive MFPI learning than students who receive conventional learning based on high MPK and medium MPK. The Sig value of the data on increasing students' mathematical multi-representation abilities based on low MPK is more than 0.05 so that the null hypothesis is accepted. In conclusion, there is no increase in mathematical multi-representation ability between students who receive MFPI learning and students who receive conventional learning based on low MPK. Students with low MPK always have difficulty representing their ideas because of their lack of mathematical knowledge.

Dewi and Sopiany state that students with low representational abilities find it challenging to create problem situations based on the provided data or representations. They also pay less attention to the available information. In addition, Suryowati (2015) revealed that students had not interpreted real-world problems into mathematical representation problems. However, some researchers point out that most students fail to understand the importance of the relationship between different types of representation (Ainsworth, 1999).

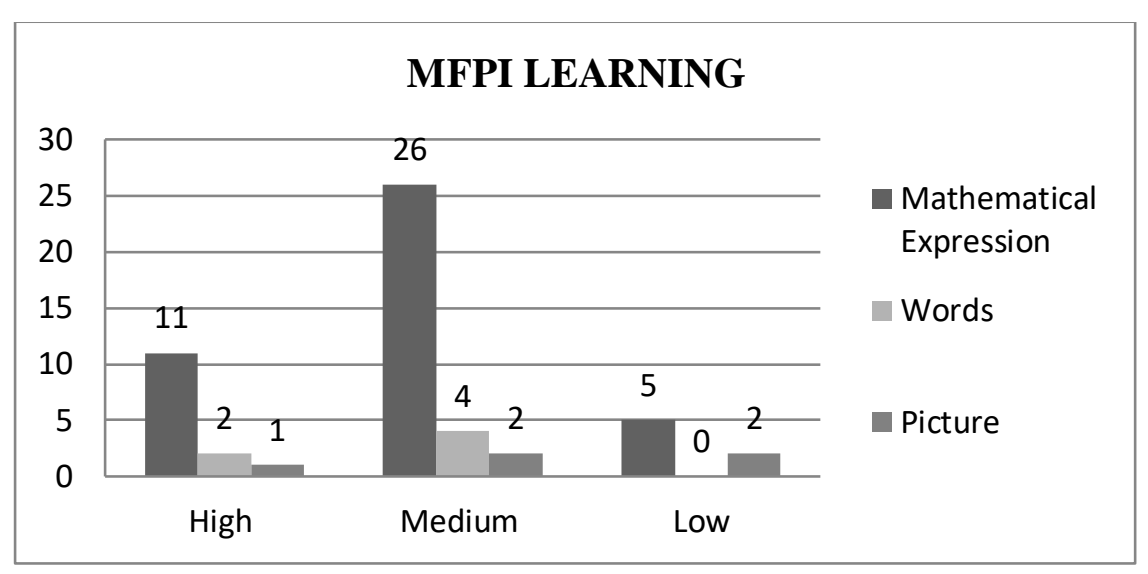

Figure 1. Graph of Multirepresentation Ability Based on Mathematical Premilinary Knowledge 


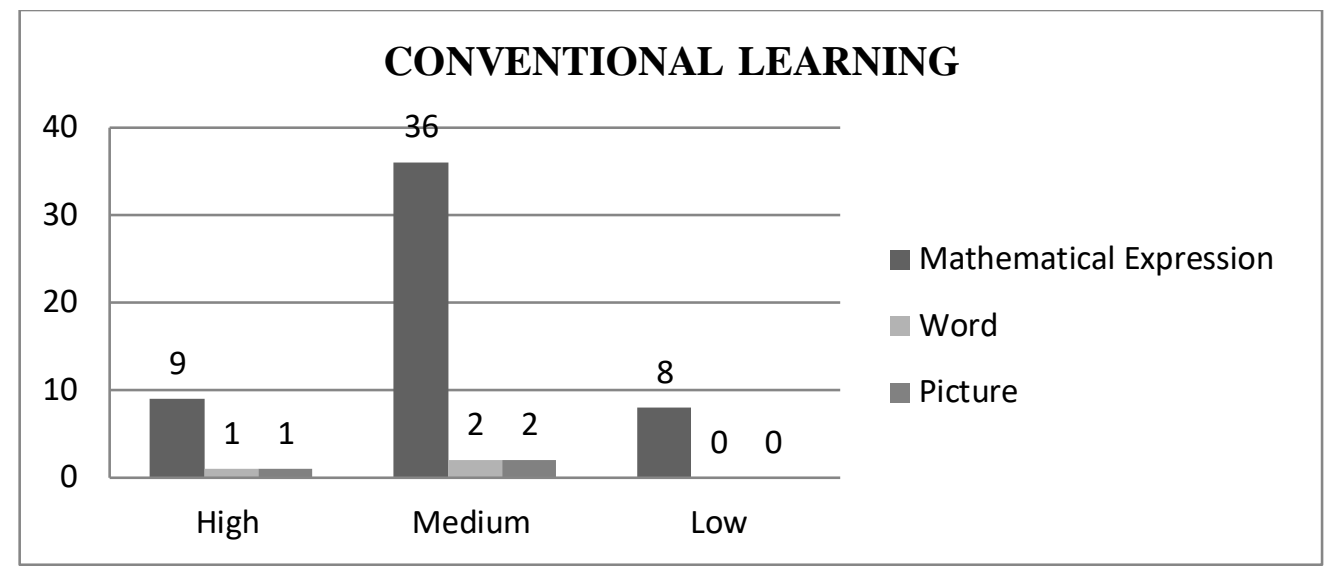

Figure 2. Graph of Multirepresentation Ability Based on Mathematical Premilinary Knowledge

Figure 1 and Figure 2 show that in classes with MFPI learning and classes with conventional learning, it is seen that most students use mathematical expressions. Bas ed on the results of this study, about $40 \%$ of students from both classes answered the questions using at least two representations, namely pictures and mathematical expressions. Students use pictures to clarify the information in their minds so that from the pictures, students find solutions. Angels et al. (2008) stated that many activities in everyday life are abstract, so visual explanations such as text or images are needed. For representations using words, only $10 \%$, most students directly use representations with mathematical expressions.

Based on Apriani's research (2016), students prefer to use visual representations to make it easier to work on problems. Nopitasari (2017) states that students with high initial mathematical abilities can present solutions with verbal, symbolic, and visual representations (graphics). Students can offer solutions with verbal and symbolic representations. On the other hand, students with low initial mathematical abilities can only write representations but do not understand symbolic and visual representations (graphics).

Multi-representation ability allows students to come up with ideas and apply those ideas to learn effectively. This is reinforced by the research results, which states that representation impacts students' cognition, problem-solving abilities, and the ability to express understanding to others (Bezemer \& Kress, 2008). Teachers should adopt different teaching strategies to promote students doing multiple representations in the classroom, thereby improving the quality of learning (Cai \& Hwang, 2002).

Through various representations, a learning atmosphere will be created by the active role of all students. As a result, teachers must have the ability to create and use all types of 
representations in learning because these various forms of representation are interrelated and reinforce each other's explanations of concepts. Students need to form good expressions in elaborating their solutions. If students have good multi-representation skills, they will have good problem-solving skills as well.

\section{CONCLUSION}

Based on the results and discussion above, this study concludes that there is a difference in the increase in the mathematical multi-representation ability of students who receive MFPI learning than students who receive conventional learning based on high MPK and medium MPK. There is no increase in mathematical multi-representation ability at low MPK between students who receive MFPI learning and students who receive conventional learning. In both classes, the most widely used representations are mathematical expressions. In addition, about $40 \%$ of students from both classes answered the questions using at least two representations, namely pictures and mathematical expressions for representation using words only $10 \%$.

\section{REFERENCES}

Ainsworth, S. (1999). The Functions of Multiple Representations. Computers \& Education, 33(2-3), 131-152.

Angel, C., Kind, P., Henriksen, E., \& Guttersrud, Q. (2008). An Empirical-Mathematical Modeling Approach To Upper Secondary Physics. Physics Education, 43(3), 256-264.

Apriani, C. M. (2016). Analisis Representasi Matematis Siswa SMP Dalam Memecahkan Masalah Matematika Kontekstual. Skripsi Tidak Diterbitkan (Hlm. 1-81). Yogyakarta: Universitas Sanata Dharma.

Bezemer, J., \& Kress, G. (2008). Writing In Multimodal Texts: A Social Semiotic Account Of Designs For Learning. Written Communication, 25(2), 166-195.

Cai, J., \& Hwang, S. (2002). Generalized and Generative Thinking In the US and Chinese Students' Mathematical Problem Solving and Problem Posing. The Journal of Mathematical Behavior, 21(4), 401-421.

Hake, R. R. (1999). Analyzing change/gain scores. Indiana University.

Kusumah, E. C. (2016). Peningkatan Kemampuan Representasi Matematis Siswa melalui Model Means-Ends Analysis dalam Pembelajaran Matematika. Universitas Pendidikan Indonesia. 
Lesh, R., Post, T. R., \& Behr, M. (1987). Representations and Translations Among Representations In Mathematics Learning and Problem Solving. In Problems of representations in the teaching and learning of mathematics (pp. 33-40). Lawrence Erlbaum.

Nopitasari, D. (2017). Analisis Kemampuan Multi Representasi Matematis Berdasarkan Kemampuan Awal Matematis Mahasiswa. Pedagogy: Jurnal Pendidikan Matematika, 2(1).

Smaldino, S. E., Lowther, D. L., Russell, J. D., \& Mims, C. (2008). Instructional Technology and Media for Learning. Pearson Merrill Prentice Hall Upper Saddle River, NJ.

Suryowati, E. (2015). Kesalahan Siswa Sekolah Dasar dalam Merepresentasikan Pecahan pada Garis Bilangan. Aksioma: Jurnal Program Studi Pendidikan Matematika, 4(1).

Wilujeng, H., Kusumah, Y. S., \& Darhim, D. (2019). The Students' Achievement of Algebraic Thinking Ability Using Merrill's First Principles of Instruction. Journal of Physics: Conference Series, 1188(1), 12039.

Wilujeng, H (2019). Peningkatan Kemampuan Berpikir Aljabar dan Multirepresentasi Matematis serta Pencapaian Self Determination Siswa SMP Melalui Merril's First Principles of Instruction. Disertasi tidak dipublikasikan. Universitas Pendidikan Indonesia. 